\title{
Scham und Schuld
}

\author{
Monika Verbalyte
}

Accepted: 1 June 2021 / Published online: 6 July 2021

(C) The Author(s) 2021

Scrambler, Graham: A Sociology of Shame and Blame. Insiders Versus Outsiders. Cham: Palgrave Pivot 2020. 118 Seiten. ISBN: 978-3-030-23142-2. Preis: $€ 53,49$.

In this book, Graham Scrambler attempts to develop an overarching theory of shame and blame. To achieve that, he includes micro, meso, and macro research perspectives, elaborates on relations between agency, culture, and structure, and brings in neoliberalism as the deeply ingrained cause for the social patterns of blame and shame. To underpin his theory, Scrambler uses four socially vulnerable groups, socalled outsiders, as examples: migrants and refugees; the long-term sick and disabled; the homeless; and sex workers. The results of his endeavor are solid: Scrambler delivers some theoretical insights, provides a sophisticated critique of modern economic and financial structures, and illuminates various aspects of stigmatization of the four groups. However, I am uncertain whether the main objective of the book - to build an encompassing theory of shame and blame-has been achieved.

The theoretical framework, though brilliant in its parts, lacks an overall completeness. First, the main concepts of the book are underdeveloped. At the beginning, Scrambler defines shame and blame as different categories, with blame being related to moral failure or deviant behavior and shame being associated with stigma and exclusion. This differentiation (guilt vs. shame) is well known in emotion theory, attribution psychology, and philosophy, and thus is not new in its essence. What promises to be interesting is their relationship; yet after shortly defining the difference between these categories, Scrambler never really expands on their relationship, neither theoretically nor empirically. On page 80 , he briefly talks about the dialectics

Monika Verbalyte $(\bowtie)$

Interdisciplinary Centre for European Studies, Europa-Universität Flensburg

Auf dem Campus 1b, 24943 Flensburg, Deutschland

E-Mail: monika.verbalyte@uni-flensburg.de 
between shame and guilt and refers to his earlier work without, however, establishing a connection to his current book. Scrambler only states that every social situation can result in different dialectics between shame and blame, but he does not provide any guidelines for defining these dialectics. In the end, even though blame has previously been defined through failure and deviance, both concepts seem to be related to the processes of discrimination, stigmatization, and social exclusion, which further deepens the question of whether there is a benefit in drawing this distinction at all. I would have liked this - in my view, substantial - distinction between blame/ deviance and shame/stigma to be more clearly specified, especially because it has a significant impact on how we could fight these societal flaws. Blame/deviance should be much easier to counteract than shame through correction procedure, punishment, justification, or apology, whereas shame and stigma are more "sticky", harder to eliminate, and therefore more permanent.

Second, the theoretical framework is an overly general solution to the micromacro-level problem and sometimes lacks specific connection to blame and shame. Scrambler complements micro-level theories of stigma and outsiders by Irving Goffman and Norbert Elias with the economic and political colonization of the lifeworlds by Jürgen Habermas, Roy Bhaskar's critical realism, and a critique of financial capitalism. All of these macrosociological elaborations are intriguing and valuable contributions, but their relationship to the topic of shame and blame is not always clear. This is also the case with the middle-level theory of Margaret Archer's modes of reflexivity, which is intended to explain the relationship between agency and structure. There are many similar theoretical attempts to fill the gap between micro and macro levels of analyses; therefore, without stronger argumentation, these choices appear rather arbitrary.

Third, the use of four examples of outsiders strengthens the impression of a fragmented theory-building process. All of the individual empirical cases are vivid and engaging illustrations of the theory, but altogether do not serve well as its foundation. First, they are not presented in a structured way. Different cases are used for different steps of the theory-building process instead of showing, e.g., how in each single case the new theoretical framing helps to reveal dynamics of shame and blame. Thus, the impression of cherry-picking arises. However, that might have also been a result of another weakness of the book, which is that the empirical status of these examples is not disclosed. I would have liked this to have been more explicitly formulated: Were they meant to be only illustrations, or were they supposed to demonstrate the theory in action? Finally, the use of UK examples combined with the critique of global capitalism raises questions as to how universal the theory is. Do these mechanisms represent pitfalls of neoliberalism in general or of liberal social systems? How would these mechanisms work in societies with more generous regimes of welfare capitalism? Scrambler also fails to explain how UK structures interplay with economic and social structures in the countries of origin of migrants and foreign sex workers living in the UK. Do the social systems of the countries of origin have no relevance? Again, it would have been useful if Scrambler had reflected on these questions.

All in all, in my opinion, this book would have enormously profited from a review of the emotion sociology literature, as it is much more thorough in its macro- 
sociological underpinnings of the micro-sociological processes of shame and guilt and in its demonstration of the relationship between the two. For example, similar to Scrambler, emotion sociology classics Jack Katz, Thomas J. Scheff, and Randall Collins take Goffman's work as a starting point, but they amend it with very different approaches, e.g., interactionism as well as social structure perspectives. However, these to my understanding are much more suitable to explain dynamics of shame and blame than Scrambler's theoretical choices. At the meso level, therefore, examinations by Katz, Collins, Arlie R. Hochschild, and Jonathan H. Turner of how people regulate their behavior according to social norms, how they experience shame in interactions, and how status plays a role in their lives might have been more relevant. As for the macro level, Scheff, Theodor Kemper, and Jack M. Barbalet put significant effort into relating power and status structures with experiences of shame. Also to be considered in this context is Germany's own sociologist, Sighard Neckel, who revealed the dynamics between capitalism, inequality structures, and shame thirty years ago. Moreover, a variety of empirical studies in emotion sociology focus on similar groups of outsiders but could have allowed Scrambler to broaden the geography of his analyses, e.g., works on institutional humiliation of refugees in Sweden and Greece by Åsa Wettergren and works on creative identities of migrants in Germany by Yvonne Albrecht; studies on how neoliberalism transforms bureaucracy and affective governance, and on the employment of shame in devaluation of sex work by Birgit Sauer et al. in Austria; and analyses of shaming and stigmatization of the long-term unemployed, public-housing tenants, the mentally ill, and other socially vulnerable groups by Roger Patulny et al. in Australia. Being aware of the existence of this literature justifies my expectation that the least Scrambler could have done would be to refer to it and to provide a more overarching theory of shame and blame.

To summarize, this book is a useful and pleasant read for those interested in the topics of inequality and neoliberalism and how they pervade people's lives with stigmatization. It provides useful information regarding discrimination and exclusion of the analyzed social groups, and it describes how the latter attempt to counteract shaming and blaming with creative forms of agency. However, I do not think that readers looking for an introduction to the sociology of blame and shame would get what they expect. Those interested in the dynamics and interconnection of personal experiences and feeling norms of shame and blame with social institutions and structures as well as with patterns of discrimination and stigmatization should probably refer to other sources, such as those mentioned in the previous paragraph.

Funding Open Access funding enabled and organized by Projekt DEAL.

Open Access Dieser Artikel wird unter der Creative Commons Namensnennung 4.0 International Lizenz veröffentlicht, welche die Nutzung, Vervielfältigung, Bearbeitung, Verbreitung und Wiedergabe in jeglichem Medium und Format erlaubt, sofern Sie den/die ursprünglichen Autor(en) und die Quelle ordnungsgemäß nennen, einen Link zur Creative Commons Lizenz beifügen und angeben, ob Änderungen vorgenommen wurden.

Die in diesem Artikel enthaltenen Bilder und sonstiges Drittmaterial unterliegen ebenfalls der genannten Creative Commons Lizenz, sofern sich aus der Abbildungslegende nichts anderes ergibt. Sofern das betreffende Material nicht unter der genannten Creative Commons Lizenz steht und die betreffende Handlung 
nicht nach gesetzlichen Vorschriften erlaubt ist, ist für die oben aufgeführten Weiterverwendungen des Materials die Einwilligung des jeweiligen Rechteinhabers einzuholen.

Weitere Details zur Lizenz entnehmen Sie bitte der Lizenzinformation auf http://creativecommons.org/ licenses/by/4.0/deed.de.

Monika Verbalyte M. A., Mitarbeiterin am Interdisciplinary Center for European Studies der EuropaUniversität Flensburg. Forschungsschwerpunkte: Soziologie der Emotionen, Europasoziologie, politische Kommunikation und politische Soziologie. Aktuelle Publikationen: Netzwerk Europa: Wie ein Kontinent durch Mobilität und Kommunikation zusammenwächst. Wiesbaden 2020 (mit J. Delhey, E. Deutschmann A. Aplowski); Evoking Forgiveness Without Apology? Emotional Anatomy of the Political Resignation. In: Scandalogy 2: Culture of Scandals-Scandals in Culture. Köln 2020; The Power of Contact. Europa as a Network of Transnational Attachment. European Journal of Political Research 57(4), 2018 (mit E. Deutschmann, J. Delhey, A. Aplowski). 